\title{
Frekuensi dan Sebaran Teripang (Holothuridea) pada Berbagai Mikrohabitat di Pantai Teluk Lombok Kecamatan Sangatta Selatan Kabupaten Kutai Timur Kalimantan Timur
}

\author{
Anshar Haryasakti ${ }^{1}$ \\ 1Program Studi IImu Kelautan, Sekolah Tinggi Pertanian Kutai Timur, Sangatta, Kutai \\ Timur, Kalimantan Timur \\ email: haryasaktia@yahoo.com
}

\begin{abstract}
This study aimed to determine the distribution of Sea Cucumbers in the Coastal waters of Lombok Bay. Data collection had been done using quadrant transects sized $1 \times 1$ meter with zig - zag scheme whereas the distance between transect was $10 \mathrm{~m}$. The number of Sea cucumbers that had been found were 88 consisting from 3 families and were divided into 8 species. The found Sea Cucumber in Lombok Bay classified into Aspidocchirotida. The highest presence frequency of sea cucumber was found at station I. The presence frequency for Holothuria scabra was $70 \%$ followed by Ophedesoma sp. (50\%), Actinopyga miliaris (40\%), $\mathrm{H}$. vagabunda (10\%) and Stichopus variegates (10\%), respectively. Sea Cucumbers that dominate on the Coastal waters of Lombok Bay classed as Holothuridea (Holothuria scabra, H. atra, Actinopyga miliaris, $\mathrm{H}$. lescopilota).
\end{abstract}

Keywords: Sea Cucumber, Distribution, Domination, Density, Lombok Bay.

\section{ABSTRAK}

Penelitian ini bertujuan untuk mengetahui distribusi Teripang di Pantai Teluk Lombok. Metode pengambilan data yang digunakan adalah transek kwadran yang berukuran 1 $\mathrm{x} 1 \mathrm{~m}$ yang dipasang secara zig - zag dengan jarak tiap transek $10 \mathrm{~m}$. Teripang yang ditemukan selama penelitian berjumlah 88 ekor yang terdiri dari 3 famili dan terbagi dalam 8 jenis. Jenis teripang yang ditemukan di pantai Teluk Lombok ini dapat digolongkan ke dalam ordo Aspidocchirotida. Frekuensi kehadiran teripang tertinggi pada stasiun I yaitu $70 \%$ jenis Holothuria scabra kemudian Ophedesoma sp sebesar $50 \%$, disusul Actinopyga miliaris sebesar $40 \%$ selanjutnya $H$. vagabunda dan stichopus variegates masing - masing $10 \%$. Teripang yang mendominasi di Pantai Teluk Lombok adalah dari Kelas Holothuridea (Holothuria scabra, H. atra, Actinopyga miliaris, $H$. lescopilota).

Kata Kunci: Teripang, Distribusi, Dominasi, Kepadatan, Teluk Lombok.

\section{Pendahuluan}

\section{$1.1 \quad$ Latar Belakang}

Kabupaten Kutai Timur salah satu Kabupaten di Provinsi Kalimantan Timur dengan Sangatta sebagai ibu kota Kabupaten, secara geografis terletak antara $118^{\circ} 58^{\prime}$

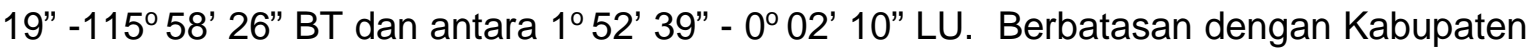
Bulungan dan Kabupaten Berau di utara, Selat Makassar di timur, Kabupaten Kutai Kartanegara di selatan dan barat. Luas wilayah daerah ini $35.747,50 \mathrm{Km}^{2}$. Kutai Timur adalah salah satu kabupaten pemekaran dari Kabupaten Kutai yang memiliki panjang garis pantai $152 \mathrm{~km}$ dengan topografi pantai yang landai memiliki keanekaragaman sumberdaya hayati laut dan tersebar dibeberapa Kecamatan pesisir (Kecamatan Sangatta Utara, Sangatta Selatan, Sangkulirang, Sandaran, Teluk Pandan, Bengalon dan Kaliorang). Di Kecamatan Sangatta Selatan terdapat Teluk Lombok yang merupakan daerah pesisir yang terletak di Desa Sangkima. Daerah ini memiliki berbagai sumberdaya 
alam hayati seperti ekosistem mangrove, terumbu karang, padang lamun dan berbagai jenis euchinodermata berupa: bintang laut, anemon laut, bulu babi dan yang menjadi objek penelitian yaitu teripang (Holothuridea).

Kordi ( 2009) menyatakan bahwa, tempat hidup Teripang adalah perairan pantai, mulai dari daerah pasang surut yang dangkal sampai perairan yang dalam. Beberapa kelompok hidup di daerah berbatu yang dapat digunakan sebagai tempat persembunyian. Sedangkan yang lain hidup pada daerah yang ditumbuhi rumput laut, lamun atau daerah berpasir, ada pula yang membuat lubang di lumpur dan pasir. Teripang hidup pada kedalaman 1 - $40 \mathrm{~m}$.

Belum adanya informasi yang jelas tentang penyebaran dan distribusi serta dominansi jenis teripang yang hidup di pantai Teluk Lombok yang melatar belakangi peneliti untuk meneliti distribusi, kepadatan serta dominansi teripang yang hidup di daerah pantai Teluk Lombok. Diharapkan dengan adanya informasi tentang distribusi, kepadatan serta dominansi jenis teripang di pantai Teluk Lombok memudahkan masyarakat untuk melakukan penangkapan.

\subsubsection{Tujuan}

Tujuan dari penelitian ini adalah untuk mengetahui sebaran teripang di Pantai Teluk Lombok, serta untuk mengetahui frekuensi kehadiran teripang di Pantai Teluk Lombok.

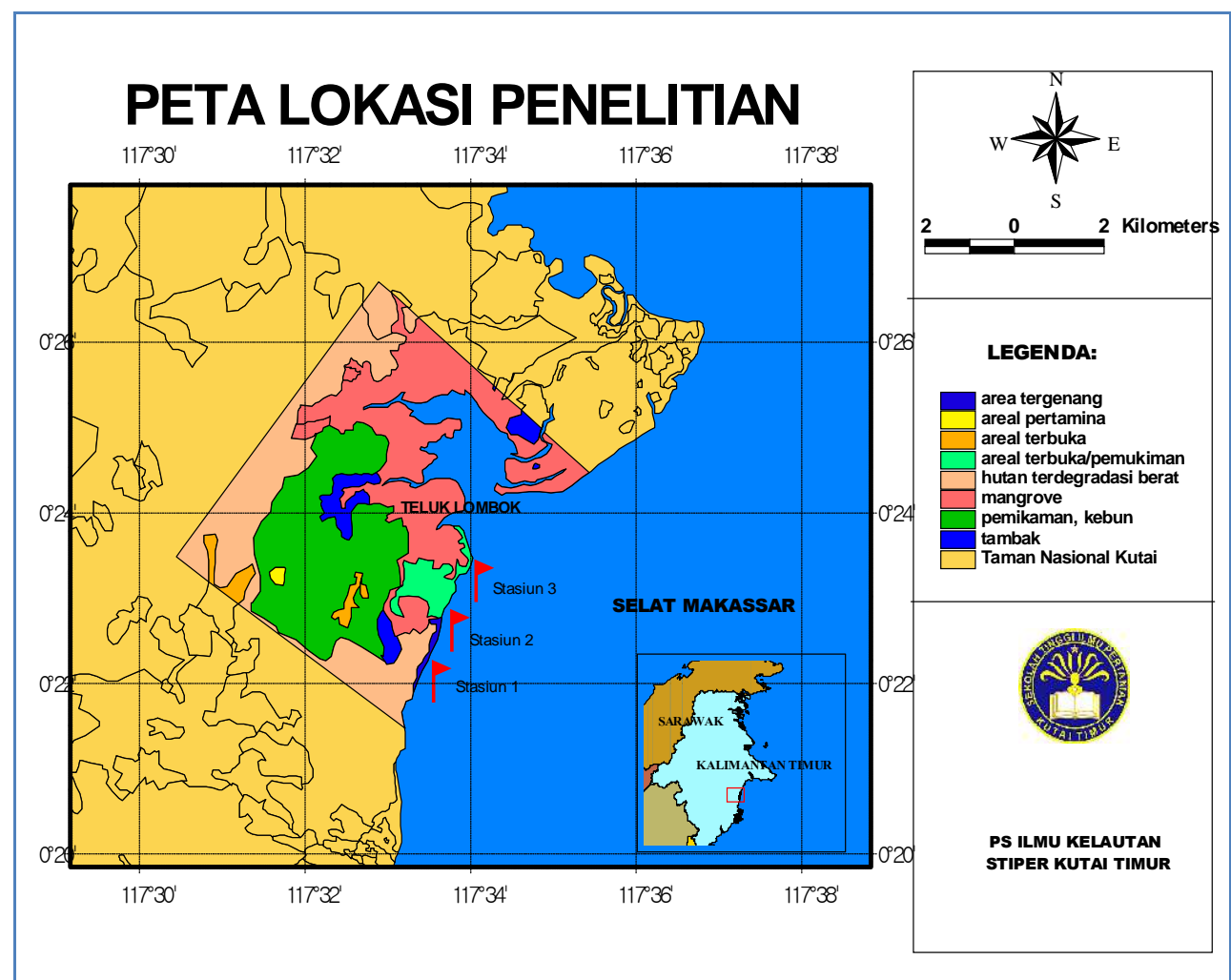

Gambar 1. Peta Lokasi Penelitian

\section{$2 \quad$ Metode Penelitian}




\subsection{Waktu dan Tempat}

Penelitian ini telah dilaksanakan selama dua bulan yaitu pada bulan Juni sampai bulan Juli 2011, bertempat di kawasan pesisir pantai Teluk Lombok (Gambar 1) Kecamatan Sangatta Selatan Kabupaten Kutai Timur.

\subsection{Prosedur Penelitian}

Pada lokasi penelitian ditarik 3 buah garis transek dengan panjang 100 meter dengan menggunakan transek kwadran yang berukuran 1 meter $x 1$ meter yang dipasang secara zig- zag dengan jarak tiap transek $10 \mathrm{~m}$. Teripang yang berada dalam kwadran transek dihitung jumlah individunya (Gambar 2). Nama jenis teripang diidentifikasi menurut The World Register of Marine Species (WoRMS Editorial Board, 2017).

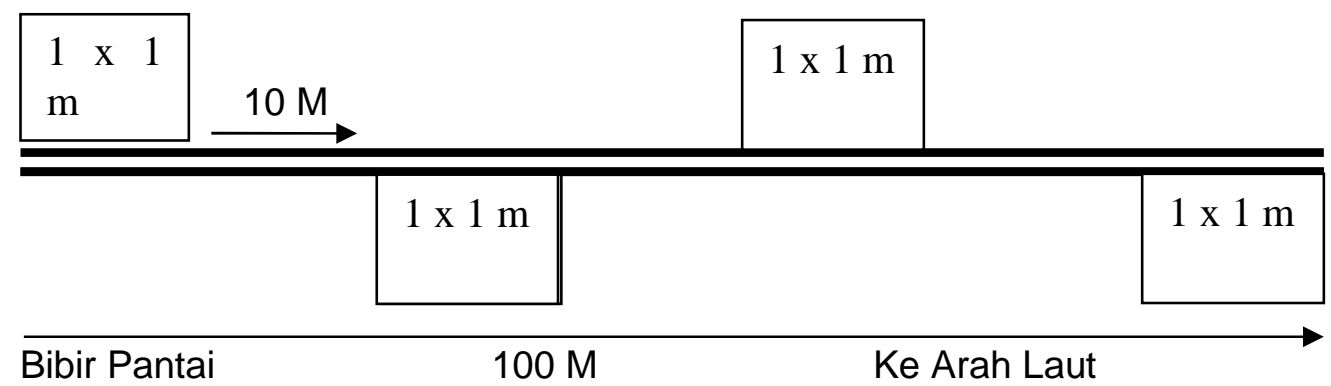

Gambar 2. Pemasangan garis transek

\subsection{Analisis Data}

Analisis data hasil pengamatan dilakukan secara deskriptif. Selain itu dilakukan pengamatan beberapa faktor abiotik yaitu; suhu, salinitas, $\mathrm{pH}$, kecerahan yang diamati bersamaan dengan pengambilan data dengan menggunakan termometer, Handrefraktometer dan kertas lakmus. Evaluasi data faktor abiotik dilakukan secara deskriptif sesuai dengan kelayakan hidup teripang. Frekuensi kehadiran dan kepadatan teripang dihitung berdasarkan Yusron (2007) yaitu:

Jumlah titik transek dimana jenis A terdapat

FK

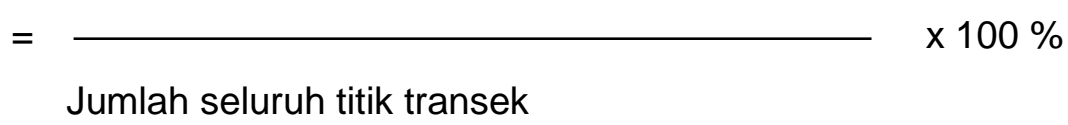

\section{Hasil dan Pembahasan}

\subsection{Pengamatan pada Stasiun Penelitian}

\section{Stasiun I}

Posisi stasiun I terletak pada N $00^{\circ} 22^{\prime} 31^{\prime \prime}$ dan E $117^{\circ} 33^{\prime} 46^{\prime \prime}$, perairan pada stasiun 1 lokasi penelitian mempunyai tipe habitat dari arah pantai menuju daerah pasang surut terdiri dari zona pasir, tumbuhan lamun dan terakhir adalah terumbu karang. Seluruh 
stasiun pengamatan merupakan perairan pantai yang landai dan bersubtrat pasir yang ditumbuhi lamun jenis Syringodium isoetifolium dan Enhalus acoroides. Karang tumbuh tidak merata akibat kerusakan yang disebabkan oleh penangkapan ikan dengan menggunakan bom dan potasium, akibat pengeboman tersebut banyak subtrat didaerah penelitian dipenuhi dengan retakan terumbu karang.

Tabel 1. Frekuensi kehadiran pada Stasiun I

\begin{tabular}{llc}
\hline No & \multicolumn{1}{c}{ Familia/species } & $\begin{array}{c}\text { Frekuensi } \\
\text { (\%) }\end{array}$ \\
\hline 1. & Holothuridae & 70 \\
& - Holothuria scabra & 10 \\
& - Holothuria vagabunda & 40 \\
2. actinopyga miliaris & 50 \\
2. $\quad$ - Ophaptidae & 10 \\
3. $\quad$ Stichopodidae & \\
& - Stichopus variegates & \\
\hline
\end{tabular}

Dari hasil pengamatan pada stasiun I ditemukan 47 ekor teripang dari 5 jenis teripang yang tergolong dalam 3 Famili. Pada stasiun I secara berurutan jenis yang mendominasi adalah Teripang Pasir (Holothuria scabra) sebanyak 32 ekor, actinopyga miliaris 6 ekor, opheodesoma sp sebanyak 7 ekor, Holothuria vagabunda sebanyak 1 ekor dan Stichopus variegatus sebanyak 1 ekor. Kelima jenis teripang tersebut ditemukan pada subtrat pasir yang bercampur dengan pecahan karang dan cangkang hewan yang ditumbuhi lamun. Pada saat pengamatan pula ditemukan Holothuria scabra dalam setiap lokasi terdapat 2 - 5 ekor. Radjab (2001) menyatakan sebagian besar teripang menyukai daerah bersubtrat pasir dan ditumbuhi lamun seperti jenis Holothuria scabra hidup secara berkelompok antara 2-10 ekor dan membenamkan diri lumpur atau pasir yang banyak ditumbuhi lamun. Teripang jenis Holothuria scabra dan $H$. Atra menyukai tempat yang berpasir dan ditumbuhi lamun selain karena di daerah padang lamun merupakan daerah yang sangat produktif juga dikarenakan sifat teripang yang peka terhadap sinar matahari. Darsono ( 2007) menyatakan bahwa habitat dengan dasar pasir karang yang ditumbuhi lamun (sea grass) merupakan tempat hidup teripang dan juga ditemukan pada habitat yang selalu di bawah garis surut terendah. Lebih lanjut Yusron (2007) menyatakan bahwa banyaknya teripang yang ditemukan di mikrohabitat karang dikarenakan perlindungan dari sinar matahari, sehingga lebih banyak teripang yang bersifat phototaxis negative. Teripang jenis Holothuria scabra menghindari sinar matahari dengan cara membenamkan diri dalam pasir serta bersembunyi dibalik tumbuhan lamun, sedangkan Holothuria atra menempeli tubuhnya dengan butiran pasir untuk memantulkan cahaya sehingga suhu tubuhnya lebih rendah (Yusron, 2007).

Teripang yang ditemukan selama penelitian berjumlah 88 ekor yang terdiri dari 3 famili dan terbagi dalam 8 jenis. Jenis teripang yang ditemukan di pantai Teluk 
Lombok ini dapat digolongkan ke dalam ordo Aspidocchirotida. Sesuai dengan hasil penelitian Radjab ( 2001) yang mengemukakan bahwa Aspidocchirotida banyak terdapat di daerah tropis. Hasil penelitian teripang di Pantai Teluk Lombok tidak memiliki perbedaan yang cukup signifikan dengan hasil penelitian di daerah lain. Hasil penelitian Yusron (2007) di perairan pantai Morella Ambon menemukan 10 jenis teripang lebih lanjut penelitian Yusron (2004) menemukan 11 jenis teripang yang bernilai ekonomis. Yusron (2007) di perairan pulau Moti - Maluku Utara menemukan 8 jenis teripang yang tergolong dalam 2 kelas (Holothuroiidae dan Stichopodidae). Hasil analisis data menunjukkan bahwa frekuensi kehadiran dan kepadatan mempunyai nilai yang cukup bervasiasi (Tabel 2).

Tabel 2. Penyebaran teripang berdasarkan mikrohabitat pada Stasiun I di Pantai Teluk Lombok

\begin{tabular}{llccc}
\hline No & \multicolumn{1}{c}{ Spesies } & Pasir & lamun & karang \\
\hline 1. & Holothuria scabra & + & + & + \\
2. & Holothuria vagabunda & + & - & - \\
3. & Actinopyga miliaris & + & + & - \\
4. & Opheodesoma sp & + & + & - \\
5 & Stichopus variegatus & - & - & + \\
\hline
\end{tabular}

Dari tabel 2 penyebaran teripang mikrohabitat menunjukan bahwa Holothuria scabra mampu menempati semua habitat, selain itu juga berkaitan dengan tingkah laku teripang yaitu upaya meredam pengaruh intensitas cahaya matahari kuat dan menghindari suhu yang relatif tinggi dengan cara berlindung dibalik karang dan lamun serta membenamkan diri dalam pasir (Aziz , 1995).

Frekuensi kehadiran tertinggi didapatkan pada jenis Holothuria scabra (70\%) Opheodesoma sp (50\%), actinopyga miliaris (40\%) dan selanjutnya Holothuria vagabunda dan Stichopus variegates masing - masing (10\%). Penelitian Yusron (1995) di perairan Kai Kecil Maluku menemukan frekuensi tertinggi diseluruh lokasi penelitian yaitu dari jenis Actinopyga mauritiana (83'3 \%) dan jenis lainnya hanya (33,3\% - 66,7\%).

\section{Stasiun II}

Stasiun II berada pada posisi N 00 $22^{\prime}$ 85” dan E117\% 33' 75”'. Kondisi lokasi pada satasiun ini memiliki subtrat yang berpasir halus dan ditumbuhi oleh lamun, daerah ini merupakan sentral kegiatan pariwisata oleh orang-orang yang berasal dari Sangatta dan Bontang. Daerah ini digunakan sebagai area bermain (banana boat, berenang, serta bola pantai)

Hasil penelitian yang dilakukan pada stasiun II menemukan jenis teripang Holothuria scabra sebanyak 4 ekor, yang terdapat di padang lamun dengan subtrat pasir halus dan padat. Jika dibandingkan dengan pernyataan Radjab (2000) yang menyatakan bahwa habitat yang baik bagi teripang adalah habitat yang memiliki subtrat lumpur, pasir 
sangat kasar kerikil, cangkang moluska dan hancuran karang, ini berkaitan dengan sifat borrowing (membenamkan diri) dari teripang tersebut.

Pada stasiun II ini hanya ditemukan teripang jenis Holothuria scabra dengan frekuensi kehadiran $30 \%$, kurangnya ditemukan pada stasiun II dikarena daerah ini merupakan lokasi dengan tingkat aktifitas yang cukup tinggi yaitu dijadikan tempat untuk berwisata (bermain banana boat dan berenang). Selain itu juga dikarena teripang tersebut membenamkan diri kedalam pasir, seperti apa yang dikemukakan oleh Yusron (2007), bahwa didaerah karang dan rumput laut cukup banyak ditemukan teripang oleh karena kebutuhan perlindungan sinar matahari.

Yusron (2007) mengemukakan jenis teripang B. Marmorata dan $H$. scabra yang terdapat di mikrohabitat pasir mempunyai kemampuan menghindari sinar matahari dengan cara membenamkan diri di pasir, dan Holothuria atra menempeli badannya dengan pasir.

Tabel 3. Pengamatan frekuensi kehadiran Teripang Stasiun II

\begin{tabular}{llc}
\hline No & \multicolumn{1}{c}{ Familia/species } & Frek \% \\
\hline 1. & Holothuridae & 30 \\
& - Holothuria scabra & - \\
2. & Synaptidae & - \\
3. & Stichopodidae & \\
\hline
\end{tabular}

\section{Stasiun III}

Posisi stasiun pengamatan III berada disebelah kiri pelabuhan Teluk Lombok dengan titik kordinat N $00^{\circ} 23^{\prime} 342^{\prime \prime}$ dan E $117^{\circ} 33^{\prime}$ 980". Pada stasiun III terdapat pohon mangrove dengan subtrat yang terdiri dari pecahan karang, cangkang moluska dan pasir yang sangat kasar serta ditumbuhi lamun yang berbatasan langsung dengan mangrove.

Tabel 4. Frekuensi kehadiran Teripang Stasiun III

\begin{tabular}{lll}
\hline No & \multicolumn{1}{c}{ Familia/species } & $\begin{array}{c}\text { Frekuensi } \\
\text { (\%) }\end{array}$ \\
\hline 1. & Holothuridae & \\
& - Holothuria scabra & 40 \\
& - Holothuria atra & 20 \\
& - Holothuria leucospilota & 20 \\
2. & - Actinopyga echinites & 40 \\
3. & -Synaptidae & 50 \\
Stichopodidac malata & 20 \\
& - Stichopus variegates & 20 \\
\hline
\end{tabular}

Hasil penelitian menemukan 6 jenis teripang dari 3 famili, yaitu Holothuridae ada empat jenis ( $H$. atra, H. scabra, H.leucospilota dan Actinopyga echinites), Synaptidae satu jenis (Synapta maculata) dan Stichopodidae dua jenis (Stichopus variegatus dan Stichopus horrens ). Hasil pengamatan selama penelitian frekuensi kehadiran jenis-jenis 
teripang yang tertangkap pada stasiun III, maka Synapta maculata memiliki nilai yang teringgi (50\%) disusul Holothuria scabra (40 \%) dan Holothuria atra, Holothuria leucospilota serta Stichopus variegates dan Stichopus horrens masing- masing (20\%). Jenis Synapta maculata yang ditemukan sebanyak 7 ekor, Holothuria scabra 6 ekor, Holothuria atra 2 ekor, Sichopus hoorrens 2 ekor, Stichopus variegatus2 ekor, Holothuria leucospilota 6 ekor dan Actinopyga echinites 13 ekor.

Dari ketiga stasiun penelitian, stasiun III lebih variatif dibandingkan stasiun lainnya, ditemukannya jenis lain yang tidak terdapat distasiun I dan II dikarena kemampuan organisme untuk menempati habitat, selain itu pula pada stasiun III kondisi perairan masih relatif alami dengan kondisi perairan yang cukup jernih dan tenang serta terdapat hutan mangrove, lamun dan karang. Radjab (2000) menyatakan bahwa teripang dapat ditemukan hampir diseluruh perairan pantai, mulai dari daerah pasang surut sampai perairan dalam dan menyukai perairan yang jernih dan relatif tenang.Subtrat pada stasiun III ini adalah pasir kasar dan pecahan-pecahan karang serta cangkang/rumah siput. Yusron (2007) menyatakan teripang umumnya menyukai mikrohabitat karang, namun 7 jenis diantaranya menempati rumput laut, 4 jenis menempati pasir dan 3 jenis menempati mikrohabitat lamun. Umumnya masing-masing jenis memiliki habitat yang spesifik. Radjab (2000) lebih lanjut hasil penelitian Radjab (2000) di perairan Kepulauan Padaido, Biak Irian jaya perairan pantai yang bersubtrat lumpur, pasir yang sangat kasar, kerikil, cangkang molluska dan hancuran karang, merupakan habitat yang baik bagi teripang yang mana sesuai dengan sifat membenamkan diri (burrowing), dari teripang tersebut, karena ukuran pasir sedang teripang dapat membenamkan diri dengan mudah. Jadi dapat dikatakan bahwa penyebaran teripang pada setiap lokasi tidak sama, baik dalam jumlah jenis maupun jumlah individu.

Tabel 5. Penyebaran teripang berdasarkan mikrohabitat pada Stasiun III di Pantai Teluk Lombok

\begin{tabular}{llccc}
\hline No & \multicolumn{1}{c}{ Spesies } & Pasir & Lamun & karang \\
\hline 1. & Holothuria scabra & + & + & + \\
2. & Holothuria atra & + & - & - \\
3. & Holothuria leucospilota & + & + & - \\
4. & Actinopyga echinites & + & + & + \\
5. & Synapta maculata & - & + & - \\
6. & Stichopus variegates & - & + & + \\
7 & Stichopus horrens & - & + & +
\end{tabular}

Daerah yang bersubtrat lamun sangat kaya akan sumber makanan bagi teripang, karena lamun merupakan sedimen trap (penangkap sedimen). Teripang adalah pemakan detritus dan lebih banyak hidup dengan membenamkan diri dalam lumpur dan pasir, sebagian besar lebih cenderung menempati habitat yang ditumbuhi lamun (Radjab, 2000). 
Pertumbuhan biota laut di daerah pasang surut sangat tinggi, disebabkan karena daerah ini merupakan tempat hidup, tempat berlindung, dan tempat mencari makan. Selain itu, kondisi lingkungan pada daerah ini sangat menguntungkan bagi pertumbuhan biota laut karena adanya dukungan dari faktor fisika, kimia, dan biologis laut. Faktor fisika-kimia laut meliputi salinitas, $\mathrm{pH}$, arus, suhu, dan kecerahan yang selalu berubahubah sangat berpengaruh terhadap kehidupan organisme di daerah pasang surut.

\subsection{Hasil Pengamatan Parameter Kualitas Air Teluk Lombok}

Adapun hasil penelitian parameter kualitasair Pantai Teluk Lombok adalah seperti yang tertera pada table 6 .

Tabel 6. Parameter Kualitas Air Pantai Teluk Lombok

\begin{tabular}{lcccc}
\hline & & \multicolumn{3}{c}{ Parameter } \\
\cline { 3 - 5 } No & Stasiun & $\mathrm{pH}$ & Suhu $\left({ }^{\circ} \mathrm{C}\right)$ & Salinitas $(\%)$ \\
1 & & 8 & 34 & 35 \\
2 & I & 9 & 33 & 37 \\
3 & II & 8 & 40 & 34 \\
\hline
\end{tabular}

Hasil pengukuran suhu air laut pada daerah pasang surut di pantai Desa Sangkimah Dusun Teluk Lombok Kabupaten kutai Timur dengan menggunakan termometer dapat dilihat pada tabel 6 yang menunjukan suhu pada derah pasang surut berkisar antara $33-40^{\circ} \mathrm{C}$. Pada stasiun 1 suhu yang diperoleh adalah $34^{\circ} \mathrm{C}$. Suhu air laut terus mengalami peningkatan dan kecenderungan kenaikan suhu pada daerah pasang surut dipengaruhi oleh penetrasi sinar matahari yang kuat.

Penelitian Radjab (2000) di perairan kepulauan Padaido Biak, Irian Jaya pada pengukuran suhu memperoleh $30-32{ }^{\circ} \mathrm{C}$. Hartati (1996) Holothuria ditemukan disemua ke dalaman dan disemua laut sehingga dapat disimpulkan bahwa mereka mempunyai toleransi pada kisaran temperatur yang luas yakni $28-30^{\circ} \mathrm{C}$ dan menjadi imotil pada suhu $36^{\circ} \mathrm{C}$, namun tentakel masih bergerak pada suhu $40{ }^{\circ} \mathrm{C}$. Jika dibandingkan dengan pengamatan suhu di Pantai Teluk Lombok diperoleh kisaran suhu $34^{\circ} \mathrm{C}$, dengan demikian maka, di Pantai Teluk Lombok masih sesuai untuk kehidupan teripang. Radjab (2000) di perairan Sulawesi Tenggara kondisi air laut yang sesuai untuk pertumbuhan teripang adalah suhu antara, $26-32{ }^{\circ} \mathrm{C}$.

Hasil pengukuran Salinitas pada daerah pasang surut pantai Teluk Lombok kecamatan Sangatta Selatan dengan menggunakan Handrefraktometer diperoleh besaran salinitas $35-37 \%$. Daerah pasang surut pantai Teluk Lombok terdapat aliran sungai kecil yang mempengaruhi salinitas perairannya. Kisaran salinitas yang terdapat di daerah pasang surut pantai Teluk lombok ini masih dapat ditolerir oleh teripang kelas holothuriadea sesuai dengan pernyataan Hartati (1996) Holothuridae hidup di daerah yang memiliki salinitas yang normal dan tidak dapat mentolerir salinitas yang rendah. 
Selanjutnya Hartati (1996) menjelaskan bahwa spesies teripang yang hidup di daerah karang dapat mentolerir salinitas $30-37 \%$.

Hasil pengukuran kecerahan diperoleh kecerahan sampai ke dalaman $50-80 \mathrm{~cm}$ dari permukaan. Hartati (1996) menyatakan bahwa umumnya Holothuria bersifat nokturnal di mana mereka aktif mencari makan pada malam hari dan menyembunyikan diri pada siang hari. Reaksi terhadap perubahan intensitas cahaya adalah bervariasi. Terhadap penerangan yang tiba- tiba, beberapa spesies bereaksi bergerak menjauh atau berpindah. Yusron (2007) menyatakan teripang peka terhadap matahari, sehingga banyak teripang yang bersifat fototaxis negatif, dalam beradaftasi dengan cahaya matahari, Holothuria atra menempeli badannya dengan butira pasir halus sedangkan jenis B. Marmorata dan Holothuria scabra membenamkan diri.

Pengukuran tingkat keasaman perairan Teluk Lombok dengan menggunakan kertas $\mathrm{pH}$ diperoleh ukuran $\mathrm{pH}$ perairan yaitu 8-9 (lihat tabel 6). Secara umum pH air laut pada daerah pasang surut pantai Teluk Lombok dapat dikategorikan basa sedang. Perubahan $\mathrm{pH}$ air laut pada daerah pasang surut dipengaruhi oleh iklim global,subtrat perairan dan masukan air tawar.

Kordi (2010) bahwa syarat pertumbuhan teripang adalah $\mathrm{pH}$ antara 6,5-8,5. Kondisi perairan pada stasiun II dari aspek kimianya adalah $\mathrm{pH} \mathrm{9,} \mathrm{salinitas} 37 \%$, suhu $33{ }^{\circ} \mathrm{C}$ dengan subtrat pasir halus yang padat dan ditumbuhi lamun. Pada stasiun II hanya ditemukan 4 ekor teripang jenis holothuria scabra. Jika dibandingkan dengan Seluruh kondisi hidrologis hasil penelitian Yusron dan Widianwari (1990) di perairan Pantai Kai Besar Maluku Tenggara, terjadi perbedaan yang signifikan antara beberapa indikator fisika dan kimianya. Kisaran suhu yakni antara $28-30^{\circ} \mathrm{C}$.

Pada saat pengukuran kondisi perairan lokasi penelitian stasiun III didapatkan ukuran suhu $40{ }^{\circ} \mathrm{C}$, salinitas $34 \%, \mathrm{pH} 8$. Perbedaan kisaran suhu yang diperoleh dari hasil pengukuran di pantai Teluk Lombok yaitu $33{ }^{\circ} \mathrm{C}$ diduga karena pengukuran dilakukan pada saat tengah hari dan pada saat kedalaman air hanya berkisar $10-15 \mathrm{~cm}$ dan perlu diketahui juga bahwa perubahan suhu sangat fluktuatif. Begitupun halnya dengan pengukuran salinitas yang dilakukan pada saat air surut terendah yang menghasilkan salinitas mencapai $37 \%$. Kisaran salinitas ini berbeda jauh dari hasil penelitian Yusron dan Widianwari (1990) yakni berkisar 32,83 - 33,80\%.

Yusron dan widianwari (1990) bahwa kondisi temperatur dan kadar garam yang ideal bagi pertumbuhan dan kehidupan teripang adalah berkisar pada suhu antara $28-31^{\circ} \mathrm{C}$ dengan salinitas 28-34\%. Hasil penelitian Radjab (2000) di Kepulauan Padaido Biak Irian Jaya memiliki salinitas $33-35 \%$ dan suhu berkisar antara $30-32{ }^{\circ} \mathrm{C}$.

\section{Kesimpulan dan Saran}


Berdasarkan frekuensi kehadiran dapat disimpulkan bahwa sebaran teripang tidak merata. Holothuria scabra merupakan jenis yang sering dijumpai dengan frekuensi kehadiran antara 30\%-70\%.

\section{Daftar Pustaka}

Aziz A. 1995. Beberapa Catatan Tentang Teripang Bangsa Aspirocirotida. LIPI. Jakarta

Darsono, A. 2007. Teripang (holothurioidea): Kekayaan Alam Dalam Keragaman Biota Laut. Puslitbang Oseaonologi-LIPI.Jakarta.

Hartati, R., 1996. Biodiversitas Teripang (Holothuroidea) di Kepulauan Karimun Jawa. IImu Kelautan Undip. Semarang.

Radjab. AW.2000. Sebaran dan Kepadatan Teripang di Perairan Kepulauan Padaido, Biak, Irian Jaya. Balitbang Biologi Laut, Pustlitbang Oseanologi-LIPI. Jakarta. .2001. Teripang Di Perairan Pasarwajo,Pulau Buton, Sulawesi Tenggara. Balitbang Biologi Laut, Pustlitbang Oseanologi-LIPI. Jakarta.

WoRMS Editorial Board. 2017. World Register of Marine Species. Available from http://www.marinespecies.org at VLIZ. Accessed 2017-12-19

Yusron E,dan Widianwari P. 1990. Struktur Komunitas Teripang (Holothuroidea) di Beberapa Perairan Pantai Kai Besar, Maluku Tenggara. Puslit Oseanografi- LIPI. Jakarta

Yusron, E. 2004. Sumberdaya Teripang Di Perairan Tanjung Pai Padaido Numfor papua. Makara Sains, Vol.8 No.3, Desember 2004: 123-127. 2007. Sumberdaya Teripang (Holothuroidea) di Perairan Pulau Utara. Pusat Penelitian Oseanografi - LIPI. Jakarta. 